\title{
粘着性流路の侵食と横断形状に関する研究* EROSION AND CROSS SECTION ON THE COHESIVE STREAM BED
}

\section{1. 緒言}

地表面を構成する土砂には，いくらかの粘着性物質が 含まれており，非粘着性の砂れきのみから成る流路床と は，非常に異なった侵食特性をもつことが少なくない。 たとえば流路横断面や縦断面をみた場合，砂れき床にお いては, 河床材料のもつ安息角がその断面形状に対する ひとつの制約条件となるが, 粘着性流路床においてはそ のような制約はなく，随所にオーバーハングさえ見られ る.このため, 粘着性流路床では, 流路位置がある程度 固定すると, その部分が集中的に侵食を受け, 深い溝を 形成することになる。裸地斜面においてしばしば見られ るリル（rill）は，このようなものであろう.

粘着性流路床における侵食現象のもらひとつの特徵 は, 土砂がはく離しにくいために, 流路長が短ければ, 水流のもつ輸送能力に達するだけの土砂が, 供給されな いことである. このため, 多くの場合, 流水のもつエネ ルギーが侵食力となって働き, それにつり合う土砂の堆 積がないため, 流路は各部で侵食される.

ところで, そのような粘着性流路床の侵食は, 砂れき 床の侵食に比べて研究が立ち遅れており, 侵食限界や流 出土砂量の推定にあたっても, 限定された条件下での経 験的な情報が取り入れられているに過ぎないようであ る. 1968 年の ASCE の報告 ${ }^{1} に$ に, それまでの研究の動 向や, 問題点がいくつか指摘されているが, それらは大 別すると, 粘性土の侵食抵抗, 侵食量, 安定流路の設計 などになる。

しかしながら，裸地斜面からの流出土砂量を予測する ような問題では, 斜面における流路の配列そのものが末

*この研究は，一部文献 12）に発表しているが，本論文は その前後にわたる研究成果を加えて, 取りまとめたもの である.

** 正会員 工修 京都大学助手 防災研究所 *** 正会員 工博 京都大学教授 防災研究所
澤 井 健 二**.芦 田 和 男*** By Kenji SAWAI and Kazuo ASHIDA

知であり,リルの発生機構を明らかにしていくことが必 要であろう.また，侵食に関与する種々の水理量を算定 する上で, 流路の横断面形状, とりわけ流路幅について 適切な情報を得ることが必要である.

本研究はそのような観点から, リルの発生を含めた流 路横断面の変形過程を中心に, 理論的ならびに実験的な 考察を行うものであるが, まず, その基礎となる粘着性 流路の侵食機構について触れることにする.

\section{2. 粘着性流路の侵食機構}

本研究でいら粘着性流路とは, 土質力学的分類でいら 粘性土に限らず，砂質土であっても，いくぶんかの粘土 分のために, 1. 緒言に述べたような侵食特性をもつ材 料からなる流路のことである.このような材料の侵食特 性は, それを構成する粘土の種類や配合状態によって非 常に異なり，一般的に記述することは困難であるが，田 中 ${ }^{2)}$ は，その侵食形態を「あばた状侵食」・「しわ状侵 食」などに分類している.

ところで，そのような砂れきと粘土の混合物から成る 流路の侵食は, 塊状のはく離が生じる場合を除けば, 砂 れきを取り囲む粘土分のはく離と, 砂れき粒子のはく離 とが交互に生じて進行するものであり, まず, 粘土の侵 食特性を把握する必要があろう.

\section{（1）粘土の侵食}

粘土の侵食速度は, 粘土の状態と水質などの条件を一 定とすれば，一般に掃流力と正の相関をもち，ある值を 境にして急激に変化することが知られている. これを限 界掃流力と称するが, 砂れきの場合のような力学的機構 のほかに, 電気化学的な機構の組み合わさった現象であ り，現在のところ理論的な取り扱いは困難である.

経験的な手法としては，限界掃流力を粘土の土塊とし てのせん断強度や, 塑性指数・分散比などと結びっけよ 


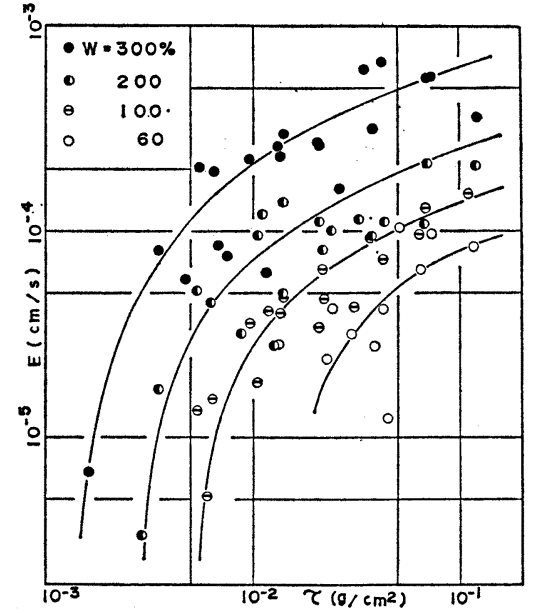

図一1 摛流力と侵食速度の関係（ベントナイト， $w:$ 含水比)

うとするものもあるが33),4)，結局は材料ごとに異なった 関係となり，侵食試験を行わざるを得ないようである. Partheniades $^{5)}$ は, さらに流水中の土砂濃度をも, 侵食 を支配する因子として取り上げ，また，掃流力の時間的 変動を確率的な現象であるとみなして, 平均掃流力と侵 食速度の関倸を導いているが，これも一般的に成り立つ ものではない.

そこで一例として，ベントナイトの侵食実験を行い， 掃流力 $\tau$ と侵食速度 $E$ の関係を調べると, 図一1 のよ うになる 含水比と飽和度（あるいは締め固め度）が挙げられる が，図一1 はほぼ飽和状態におけるものである.このよ うに, ベントナイトの侵食速度は含水比によってかなり 異なり, 含水比が小さくなるほど侵食抵抗が大きくなる が，土塊としてのせん断強度の変化（液性限界と塑性限 界とで $10^{4}$ 倍以上も異なる）に比べれば, その変化量は 少ない．また，含水比を一定とすれば，掃流力の大きい 範囲で侵食速度が摩擦速度に比例している.

\section{（2）粘土分を含有する砂れき床の侵食}

粘土分を含有する砂れき床の侵食は，それを構成する 粘土分と砂れき分のはく離特性が異なるため, 一体のも のとして取り扱らことは困難である.そこで，それらが 交互にはく離されるものと考えて,図一2 に示すように，

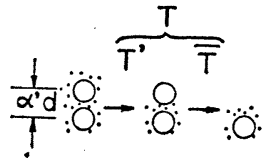

図-2 粘土分と砂れき粒子の交互 のはく離 $(d:$ 砂れき径, $\alpha^{\prime} d:$ 粒子閒隔)
ひとつの砂れき粒子のは く離過程に要する時間 $T$ を, 周囲の粘土が侵食 されて砂れきが移動しや すい状態になる時間 $T$, と,そのような状態にな ったのち, 実際に砂れき
が移動するまでの時間 $\bar{T}$ とに分割する。ここに「移動

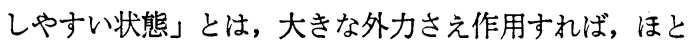
んど瞬間的に粒子が移動するような状態のことである. 厳密にはどのような状態においてどんなに大きな外力が 作用しても, 粒子のはく離が完結するには, ある程度の 時間が必要であるが，その時間は粒子の露出度によって 異なるから，それをある基準によって分けるのである.

$\bar{T}$ は，周囲の粘土がほとんど取れた状態において，砂 れき粒子が移動するのに要する時間であるから, 通常の 砂れき床において, 同じ位置から砂れきが飛び出す時間 間隔にほぼ等しいものと考えられる。これはすなわち， 平衡状態の流砂機構における単位時間の砂れきの移動確 率 $P_{s}$ の逆数であって,

$$
\bar{T}=1 / P_{s}
$$

となるが, $P_{s}$ は, 平衡流砂量 $\bar{q}_{b}$ と,

$$
\bar{q}_{b}=P_{s}(1-\lambda) \bar{l} d
$$

のような関係にあるので, 式 (1) および (2) より $P_{s}$ を消去すれば，

$$
\bar{T}=(1-\lambda) \bar{l} d / \bar{q}_{b}
$$

となる.ここに, 入 は砂れき床の空幥率, $\bar{l}$ は砂れきの 平均移動距離, $d$ は砂れきの直径である. また, 平均移 動距離は主として粒径によって決まり7),

$$
\bar{l}=A_{L} d
$$

と表わされる.ここに, $A_{L}$ は $10^{2}$ 程度の係数である。

通常の砂れき床では, ひとつの砂れきが移動しても, そのすぐ下に別の砂れきが露出しており, また, 上流か ら流れてきた砂れきがそこに堆積することもあって，常 に「移動しやすい状態」が保たれるわけであるが，粘土 分を含有する砂れき床では, 次の粒子が露出するまでに かなりの時間が費やされる.これが $T^{\prime}$ であり, 粘土の みの河床が $d$ だけ低下する時間を $T_{c}$ とし, 係数 $k_{1}$ を 導入して,

$$
T^{\prime}=k_{1} T_{c}
$$

と表わすことにすれば，侵食の周期 $T$ は

$$
T=k_{1} T_{c}+\bar{T}
$$

となる. $k_{1}$ は砂れきの存在が粘土の侵食に及ぼす効果 ならびに砂れきの存在距離間隔によって決まるもので, 実験によって求めなければならない， $T_{c}$ は粘土の侵食 速度を $E$ とすれば,

$$
T_{c}=d / E
$$

であるが， $E$ の值は前節に述べたように, 粘土の種類や 状態によって異なり, 現在のところ実験的に求める以外 に適当な方法がないようである.

以上のことから, 粘土分を含有する砂机き床の侵食速 度は, 砂れき粒子の存在間隔を $\alpha^{\prime} d$ とすれば $\partial z / \partial t=\alpha^{\prime} d / T=\alpha^{\prime} /\left\{k_{1} / E+A_{L}(1-2) d / \bar{q}_{b}\right\}$ 
となる.ここに, $z$ は河床面の高さ (下向きが正), $t$ は 時間である.

そこで, 混合河床の低下速度, 砂河床の平衡流砂量, および粘土の侵食速度の実測值から， $T, \bar{T}, T_{c}$ を求め て，上記の関係を検討してみることにする．混合河床の 構成材料は, 粒径 $1 \mathrm{~mm}$ の砂とベントナイトと水を重 量比 $9: 1: 3$ に練り混ぜたもので, 砂の間隚を, 含水 比 $300 \%$ でほぼ飽和状態のベントナイトが埋め尽くし ている状態である. $\bar{q}_{b}$ と $\partial z / \partial t$ は同じ水理条件におけ る実験によって測定し， $E$ は前節の 図一1において,そ れらと同じ掃流力に対する含水比 $300 \%$ の場合の值を 用いた。

実験例 $1 \quad q=71 \mathrm{~cm}^{2} / \mathrm{sec}$ の場合（ $q$ は単位幅流量）

$$
\begin{aligned}
& T=d /(\partial z / \partial t)=383 \mathrm{sec}, \\
& \bar{T}=100(1-\lambda) d^{2} / \bar{q}_{b}=6.5 \mathrm{sec}, \\
& T_{c}=d / E=375 \mathrm{sec}
\end{aligned}
$$

実験例 $2 q=16.5 \mathrm{~cm}^{2} / \mathrm{sec}$ の場合

$$
\begin{aligned}
& T=2083 \mathrm{sec}, \\
& \bar{T}=1600 \mathrm{sec}, \\
& T_{c}=495 \mathrm{sec}
\end{aligned}
$$

ただし， $A_{L}=100, \alpha^{\prime}=1$ とおいた。

このように, 2 例とも

$$
T \fallingdotseq \bar{T}+T_{c}
$$

が成り立っており，これを式（6）と比較すると，

$$
k_{1} \doteqdot 1
$$

となる. 勾配はいずれも $1 / 100$ で, 例 1 はかなり活発 な流砂が存在する場合, 例 2 は限界掃流力を少し上回っ た場合であるから，式（9）あるいは（10）は，かなり 広範囲にわたって成立するものと考えられる.

なお, 砂質土よりも粘性土の方が侵食抵抗が大きいと いらばく然とした概念は, 限界掃流力の大小を比較して いるのか, ある掃流力における侵食速度の大小を比較し ているのかを明確にしなければ意味をなさない。たとえ ば上の例の場合, 例 1 では, 粘土分さえ侵食されれば, 砂粒子はきわめて容易に離脱するが, 例 2 では砂粒の離 脱に要する時間が, 粘土分の侵食時間よりもはるかに長 くなっている.すなわち,ベントナイトは粒径 $1 \mathrm{~mm} の$ 砂に比べて, 大きな掃流力のもとでの侵食抵抗は大きい が，限界掃流力はずっと小さいのである.

また, 砂れき床では粒子の移動の活発さと侵食の進行 (正味の河床低下) が必ずしも一致せず, 流下方向への

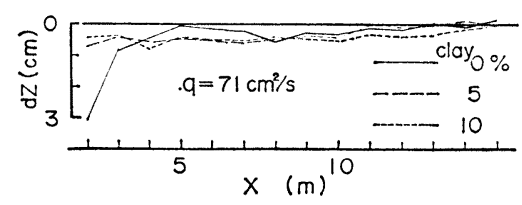

図一3 俊食後の河床縦断形状 $(x<2 \mathrm{~m}$ は固定床 $)$
水理量の変化に対応して河床が変動するが, 粘着性流路 床では各点の水理量そのものに対応して侵食が進行す る. 図-3 は, 先の例 1 と同じ条件での砂河床と粘着性 河床における通水 30 分後の縌断形を示したもので, 砂 河床では上流部（固定床から移動床への移行部分）だけ が激しく洗掘されて, 少し下流からは活発な流砂がある にもかかわらず，ほとんど低下していないのに対し，混 合河床では緩慢にではあるがかなり長い区間にわたって ほぼ平行に低下が生じ，ある距離においてそれが急に止 まっている．また，そのような洗掘索受ける範囲は，砂 河床においては時間とともに伝播するが, 粘着性河床に おいてはほぼ定まっている。

\section{（3） 粘着性流路における流砂量}

前節に述べたように，砂れき床では粒子が「移動しや すい状態」にあるため, 河床からほぼ流水のもつ輸送能 力に見合うだけの土砂が供給され，流砂量は各点の水理 量と対応づけられる.これに対して粘着性流路では, そ れだけの土砂が供給されるにはかなりの距離を要し, 流 路長がそれよりも短ければ流砂量は流路長に依存する. このことは, 岩垣・土屋帛によっても指摘されており, 一様流による土のはく離量は斜面の長さとともにほぼ直 線的に増大することが見い出されている.

一方, 自然斜面に対する USDA ${ }^{9)}$ などの土㙵流亡式 によれば，単位面積あたりの流出土砂量が斜面長の 0.5 乗に比例し, 斜面全体からの流出土砂量は斜面長の 1.5 乗に比例して増大するが,これは斜面長の増加に伴う流 量増加に起因するものであろう.

ところで水理条件が流下方向に一定の場合, 斜面長の 増加に伴って流砂量がどこまでも増加するとは考えられ ず，ある限界が存在するものと思われる．そこで粘着性 河床の流砂機構について次のようなモデル化を行い, 流 路長と流砂量の関係について考察する.

粘土分を含んだ砂れき床が侵食されると, 砂れき分は 河床と流水の間を往復しながら徐々に流下するが, 粘土 分はほとんど水流と一体となってただちに流下してしま う.したがって, 流砂現象を侵食と堆積の過程に分けて 考えた場合, それらの過程における土砂の構成成分は異 なっており, その結果河床面は, まだはく離していない もとの混合物の露出部といったん侵食されたのち, 輸送 の過程で堆積している砂れきの被覆部とで異なった性質 をもつようになる。

図一4 は, そのような流路の流下方向の微小区間にお ける土砂収支を模式的に表現したもので, 河床面におけ る粘土分を含有した土砂の部分を領域 I, 輸送過程にあ るはく離した砂れきの部分を領域II とし, 後者の面積割 合を $p$ とおいている. 河床の単位面積から単位時間に 


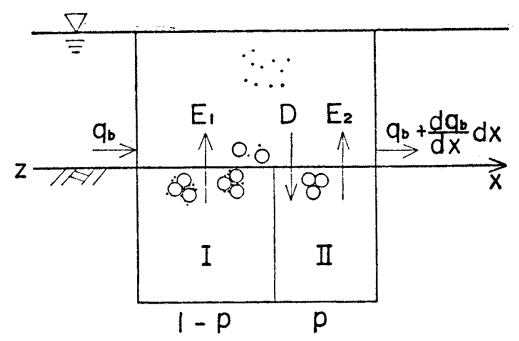

図一4粘土分を含有した砂れき床の土砂収支

侵食される砂れきのうち, 領域 I からのものを $E_{1}$, 領 域 II からのものを $E_{2}$, また堆積量を $D$ とすれば, $E_{2}$ と $D$ はほぼつり合うから流砂の連続式は,

$$
\partial q_{b} / \partial x=E_{1}+E_{2}-D \fallingdotseq E_{1}
$$

となる.ここに， $q_{b}$ は粘土分を除外した単位幅流砂量， $x$ は流下方向の距離である.

ここで, 領域 Iについての単位面積・単位時間あたり の砂れきの侵食量を $\bar{E}_{1}$ とすれば,

$$
E_{1}=\bar{E}_{1}(1-p)
$$

と表わされる.一方, 流下方向への $q_{b}$ の増加に伴って $p$ も増加するが，図一3で見たように河床低下量は徐々に 減少するものではなくて, $p$ が比較的小さなある 值に 達する所までほぼ平行に低下したのちそれが急に止まっ ている. したがって, その場所における流砂量を $\bar{q}_{b}$, そ れよりも上流の流路長を $\bar{x}$ とすれば，実験結果ならび に式 (11), (12) より,

$$
q_{b} \fallingdotseq \bar{E}_{1} x \fallingdotseq \bar{q}_{b}(x / \bar{x}) \quad(x<\bar{x}) \text {. }
$$

となる. $\bar{E}_{1}$ は前節に求めた河床低下速度に, 砂れきの 空げき率を掛けて求めることができ，また， $\bar{q}_{b}$ は平衡 流砂量であるから, 従来の流砂量式より算定することが できる.このように，pの比較的小さな值において侵食 が止まり，平衡状態が現われる理由としてはそれ以上の $p$ に対しては砂れきの移動距離が急激に短くなって, 余 分に供給された土砂が容易に堆積すること，ならびに遮 蔽効果が顕著になって，侵食が抑制されることなどが挙 げられる。

図-5 は, 流路長と流砂量の関係について実験結果を 示したもので, 砂河床の場合は流路長による流砂量の差

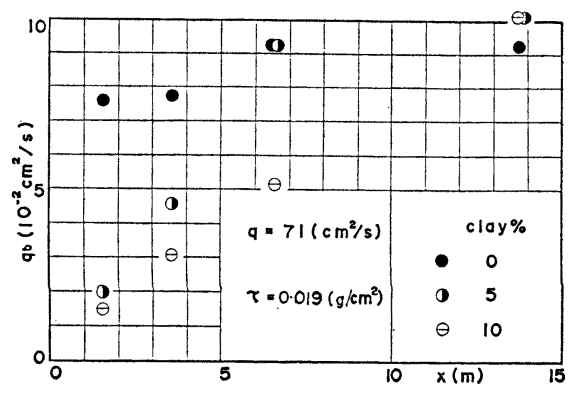

図一5 流路長と流砂量の関係
異がほとんどない が, 混合河床の場合 は流路長が短い間は 流路長の増加に伴。 て流砂量がほぼ直線 的に増加し, それが ある值に達するとほ とんど変化しなくな っている. そして, その值は粘土含有率 によらずほぼ一定で ある.もっとも，砂

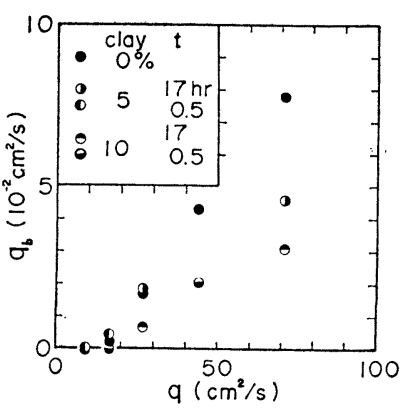

図一6 流量と流砂量の関係（流路長 $3.6 \mathrm{~m}, t:$ 敷きならし後の時 間)
れき床の場合には, 洗掘の進行に伴って勾配が緩くな り，その影響圈では流砂量が時間とともに減少する.こ れに対して粘着性流路では, 流路長がそれほど長くなけ ればほぼ平行に低下が進むから，流砂量洔間的にさほ ど変化しない。

図一6 は流路長を一定として, 流量 $q$ と流砂量 $q_{b}$ の 関係を示したもので, 流量が大きくなると砂河床の場合 には $q_{b}$ が $q$ にほぼ比例して増加するのに対し, 混合河 朱の場合にはそれほど増加しない。これは流量の小さい 範囲では, 混合河床の流砂量がもっと短い流路長ですで に平衡流砂量に達しているが, 流量が大きくなると,こ のような流路長ではまだ平衡状態に達していないことに 相当する.すなわち, 平衡状態の現れる流路長 $\bar{x}$ は, 流量あるいは掃流力と正の相関をもつ.

\section{3. 粘着性流路床の横断面形状}

一般に開水路の流れを取り扱ら場合, 流量 $Q$ と勾配 $I$ が独立変量として与えられることが多く, それらの值 から他の種々の水理量 (水深や流速など) を求めるに は, まず, 流路の断面形状, とりわけ流路幅 $B$ に関する 情報を得ることが必要である．たとえば裸地斜面からの 流出土砂量を予測しようとする場合, 斜面上に形成され る個々のリルやガリーの配列には, 確率的な要素が介在 するが ${ }^{10)}$, 斜面全幅のうちで流路部分の占める割合など には統計的な規則性が見られ の他の物理量といかに結びっけるかが問題となってい る.

これには 2 つの問題があり,ひとつは流路間隔の問 題, すなわち斜面におけるリルやガリーの形成の問題で あり，もらひとつは形成された個々の流路の規模の問題 である. 以下，それぞれの問題について考察を進める が，まずその基礎となる流路横断面内の掃流力分布につ いて考察する. 


\section{（1）流路横断面内の㛿流力分布}

流れが流下方向に変化しない場合，すなわち等流にお いて 2 次流の影響を省略し, 流体内に働くせん断力の原 因が流速勾配にあるものとすれば,図一7 に示すように， 断面を等流速線の直截線群で分割したとき, 分割線上で

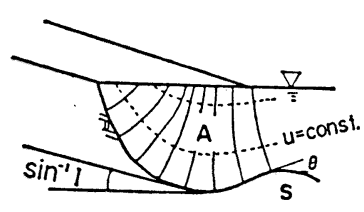

図一7等流速線の直截線群に よる断面分割
はその法線方向に流速 勾配が存在しないから せん断力が働かない. したがって，そのよう な分割線にはさまれた 流体塊に作用する重力 の流下方向成分は，壁 面せん断力すなわち掃流力のみによって受け持たれる. そこで, 分割された面積を $A$, 潤辺に沿う距離を $s$ と

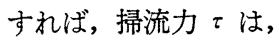

$$
\tau=\rho g(d A / d s) I
$$

となる.ここに, $\rho$ は密度, $g$ は重力加速度, $I$ は勾配 である。

任意の形状をもつ断面において, 等流速線を求めるこ とはきわめて困難であるので, 通常は断面を鉛直線で分 割し, 局部水深 $h^{\prime}$ と壁面の傾き $\theta$ を用いて, $\tau=\rho g h^{\prime} I \cos \theta$

と近似されるが，それでは鉛直な側岸の掃流力が評価で きず，また，底面においても，曲率の大小にかかわら ず，常に深部の掃流力が大きくなって不合理である．そ こで式 (14) と, 流速分布に関する壁法則を連立させる ことによって，掃流力分布を求めてみよう．まず，掃流 力分布の第 0 近似として, 摩擦速度を壁面（側岸と底面 を区別せずに総称したもの）で一様とおけば，壁法則に より断面内の各点の流速は, 壁面からの距離によって決 定されることになる.すなわち，断面内の等流速線の第 1 近似として, 壁面からの等距離線が得られる. 次にこ の等距離線群に対する直截線によって断面を分割すれ ば，式（14）によって掃流力分布が求まる.さらにその 掃流力分布に対して壁法則を適用すれば，流速分布の第 2 近似が得られるが, 掃流力が不均一な場では 2 次流の 存在が無視できず，壁法則自体の精度が問題となるの で,これ以上の展開は行わない.

ところで, 壁面からの等距離線に対する直截線は, 壁 面上の同一の点を最短距離とするような点の集合にほか ならないから, 壁面にたてた内向き法線の一部となる. すなわち，図一8 に示すように，断面内の法線上に壁面 上の 2 つ上の点を最短距離とするような点（等距離分 割点）がある場合には，その点まで，また，そのような 点がない場合には, 自由水面までの部分である. この法 線分の長さを $l$ とすれば, 式 (14) は次のようになる.

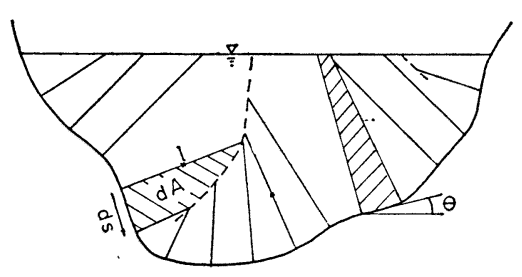

図一8 壁面の法線群による断面分割

$$
\begin{aligned}
\tau & =\rho g\{1-(l / 2) d \theta / d s\} l I \\
& =\rho g(1-\kappa l / 2) l I \ldots \ldots \ldots .
\end{aligned}
$$

ここに, $\kappa$ は壁面の曲率である.

流路壁面にとがりがある場合, むしくは水際部分がオ 一バーハングしている場合には, ある範囲で平均操作を 加えることにより, 任意形状流路横断面内の壁面全体に わたる掃流力分布を，眓解的に求めることが可能とな る.

式 (16) は，次節以下における理論展開の根幹をなす ものであり，直接的な検証のなされることが望ましい が，現段階ではたとえば正弦波のような波状断面をもつ 水路上の掃流力分布を直接に測定することはむずかし く, 比較的単純な事例について直接的な検証が行えるほ かは, この式の誘導過程, 式のもつ定性的特徵, この式 を用いて導かれる結果と実際現象との対応など, 種々の 側面から間接的な検証を行わざるを得ないであろう.

図一9 は, 幅・水深比が約 3 の円弧断面について, 式 （15） と式（16）加求めた 掃流力分布を断面平均值に 対する比で 表示し, 流速分布の実測值から求めた掃流 カ13) と比較したもので, 式 (16) は式（15）よりもかな り精度のよいことがわかる.ここに，断面平均掃流力 $\overline{\boldsymbol{\tau}}$ は, どちらの式においても通常のものと一致する.すな わち,

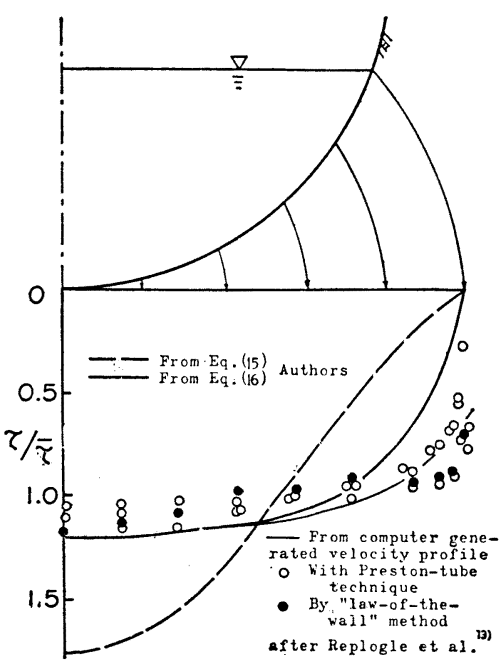

図一9 円弧断面における㛿流力分布 


$$
\begin{aligned}
\bar{\tau} & =\frac{1}{s} \int_{0}^{s} \rho g \frac{d A}{d s} I d s=\frac{1}{s} \int_{0}^{B} \rho g h^{\prime} I \cos \theta \frac{d s}{d x} d x \\
& =\frac{\rho g A I}{s}=\rho g R I
\end{aligned}
$$

である.ここに, $s$ は潤辺長， $B$ は流路幅， $R$ は径深 である。

また, 式 (16) では曲率の存在によって, 壁面の凸部 における掃流力の集中や, 凹部における遮蔽効果が表現 されており，式（15）に見られた不合理は解消する.

式 (16) における $l$ は, 壁面上の各点がもつ影響圈の 長さに相当し，一般的に表示することは困難であるが， 特に壁面からの等距離分割線（等距離分割点の集合）が 断面内に存在しない（法線群が断面内で交錯せずに水面 と交わる）か，または鉛直（たとえば，左右対称断面の 中心軸）の場合には, 容易に数式で表現することがで き, 直交座標を用いると式（16）栨のようになる.

$$
\left.\begin{array}{c}
\frac{\tau}{\rho g H_{0} I}=\left\{1+\left(\frac{d y^{\prime}}{d x^{\prime}}\right)^{2}-\frac{1}{2} \frac{d^{2} y^{\prime}}{d x^{\prime 2}} F^{\prime}\right\} \\
\cdot F^{\prime} / \sqrt{1+\left(\frac{d y^{\prime}}{d x^{\prime}}\right)^{2}}, \\
F^{\prime}=\min \left\{1-y^{\prime},\left(x^{\prime}-x_{0}^{\prime}\right) \frac{d x^{\prime}}{d y^{\prime}}\right\}
\end{array}\right\}
$$

ここに, $H_{0}$ は水位, $x_{0}$ は等距離分割線の $x$ 座標で, $x^{\prime}, y^{\prime}$ はそれぞれ壁面の座標 $x, y$ を $H_{0}$ で基準化した ものである. $d y^{\prime} / d x^{\prime}, d^{2} y^{\prime} / d x^{\prime 2}$ がともに小さい場合に は, 式 (17) は式 (15) と一致する.

さらにあとで述べるように，粘着性流路床における横 断方向底面凹凹の発達・減衰や, 平衡横断面など, 本モ デルを用いて導かれる種々の結果は, 実験事実によく適 合する.

したがって, 式 (16) に示した掃流力算定法は, 本論 文における適用範囲ではかなりの妥当性を有するものと 判断されるが, 今後, より直接的な検証を加えるととも に，適用範囲を広げるため 2 次流の効果や不等流の影響 をも導入していきたいと考えている.

\section{（2）*）横断面形状の追跡法}

前章に述べたように，粘着性流路床は掃流力の流下方 向変化でなくて, 各点の掃流力そのものに対応した侵食 を受けるから，横断面内の掃流力分布ならびに掃流力と 侵食速度の関係が得られれば, 流れを等流で近似するこ とによって流路横断面の変形過程が追跡できる. 通常, 流路変動の解析では底面と側岸を区別し, 前者について は鉛直方向，後者については水平方向に変位を追跡する が，侵食・堆積現象は壁面における土砂粒子の着脱によ って生じるものであるから，本来は壁面の法線方向に変 位を追跡するのが妥当であろう．また，与えられた流路

*) 本節の考え方は, 文献 14）に述べたものと同じである.
条件と流量条件 $Q$ に対して, 水位を決定するには水流 の抵抗則が必要である.

以上のことから, 流路横断面の変形過程を追跡する基 礎方程式は次のようになる.

$$
\begin{aligned}
& d n / d t=E \\
& E / E_{0}=\left(u_{*} / u_{* 0}\right)^{n} \\
& u_{*}=\sqrt{g(d A / d s) I} \\
& v=\sqrt{8 g R I / f} \\
& Q=A v
\end{aligned}
$$

ここに, 式 (18) の $n$ は壁面の外向き法線方向変位, $u_{*}$ は摩擦速度 $(\sqrt{\tau / \rho}), v$ は平均流速, $f$ は抵抗係数 である.また, 式 (19) における $u_{*_{0}}$ はある基準摩擦速 度であり, 指数 $n$, および $u_{* 0}$ に対応する侵食速度 $E_{0}$ は土の種類や状態によって決まる量である.

そこで基準水深 $H_{0}\left(\equiv u_{* 0}{ }^{2} / g I\right)$ を用いて, 上の式系 を無次元化すると, 次のようになる.

$$
\begin{aligned}
& d n^{\prime} / d t^{\prime}=E^{\prime} \\
& E^{\prime}=u_{*}{ }^{\prime n} \ldots \ldots \ldots . . . . . \\
& u_{*}^{\prime}=\sqrt{d A^{\prime} / d s^{\prime}} \\
& v^{\prime}=\sqrt{8 R^{\prime} / f} \ldots . . \\
& Q^{\prime}=A^{\prime} v^{\prime} / \sqrt{8 / f}
\end{aligned}
$$

ここに, $n^{\prime}=n / H_{0}, t^{\prime}=t \cdot E_{0} / H_{0}, \quad E^{\prime}=E / E_{0}, \quad u_{*}^{\prime}=u_{*} /$ $u_{* 0}, A^{\prime}=A / H_{0}{ }^{2}, s^{\prime}=s / H_{0}, v^{\prime}=v / u_{* 0}, R^{\prime}=R / H_{0}, Q^{\prime}=$ $Q /\left(\sqrt{8 / f} u_{*_{0}} H_{0}^{2}\right)$ である.

流量が一定の場合には，これらの式系を，

$$
f Q^{, 2}=f A^{, 2} R^{\prime}=f A^{\prime 3} / s^{\prime}=\text { const. }
$$

の条件のもとで解けばよい.

\section{（3）横断面内における底面凹凸の発達・減衰とリル の発生}

一般に, 斜面あるいは流路底面の横断方向には, 種々 の規模の擾乱が混在しており，そのうち凸部よりも凹部 の方が速く侵食されるものは発達し, 凹部よりも凸部の 方が速く侵食されるものは減衰する．このような擾乱の 盛衰を解析する手法としては, 種々の分野で線形安定理 論が用いられているが, 流路の分裂のように平均量から のずれが，平均量と同程度の大きさを有するような現象 の解析には，それは適用できないであろう．そこで本研 究では, 線形安定論におけるような微小振幅に限定する ことなく, 任意の波高をもつ凹凸の峰と谷における諸量 の比較から, 擾乱の発達・減衰を論じる.

a）正弦波近似による底面凹凸の発達・減衰

一般に，不規則波形は種々の正弦波の重ね合わせから 成るものと解されるが，その成分波もしくは代表的な単 一の波長をもつ正弦波を取り扱らことが，その解析の基 礎となる，そこで，図一10に示すように，横断面内の 壁面の凹凸を単一の波長をもつ正弦波, 


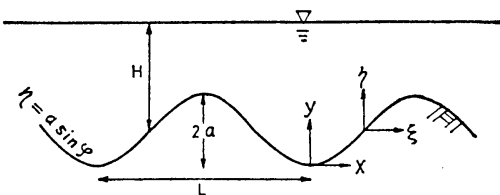

図一10 横断面内底面凹凸の正弦波による表示 $(\varphi=2 \pi \xi / L)$

$\eta=a \sin (2 \pi \xi / L)$

で近似する。ここに， $(\xi, \eta)$ は変曲点を原点とする壁面 の座標, $L$ は波長 (うね間隔)， $a$ は振幅 (半波高) で, $(\xi, \eta)=(x-L / 4, y-a)$ である.このような正弦波上の 掃流力分布を, 式 (17) によって求めれば,

$$
\left.\begin{array}{l}
\frac{\tau}{\rho g H I}=\frac{\left\{1+\delta^{2} \cos ^{2} \varphi+\left(\delta^{2} / 2 \alpha\right) \sin \varphi \cdot F^{\prime}\right\} \cdot F^{\prime}}{\sqrt{1+\delta^{2} \cos ^{2} \varphi}} \\
F^{\prime}=\min \left[1-\alpha \sin \varphi, \alpha(2 \varphi+\pi) /\left(2 \delta^{2} \cos \varphi\right)\right]
\end{array}\right\}
$$

となり,一方, 平均掃流力は,

$$
\begin{aligned}
\frac{\bar{\tau}}{\rho g H I} & =\frac{A}{H s} \\
& =\int_{-L / 4}^{L / 4}(H-\eta) d \xi /\left\{H \int_{-L / 4}^{L / 4} \sqrt{1+\left(\frac{d \eta}{d \xi}\right)^{2}} d \xi\right\} \\
& =\frac{\pi}{2 \sqrt{1+\delta^{2}} \cdot E \sqrt{\left.E_{\delta^{2}} /\left(1+\delta^{2}\right)\right)}} \cdots \cdots \cdots \cdots \cdots(31)
\end{aligned}
$$

であるから，両者の比は，

$$
\begin{aligned}
\frac{\tau}{\bar{\tau}}= & \frac{2}{\pi} \underset{\underline{E}}{\mathrm{E}}\left(\sqrt{\frac{\delta^{2}}{1+\delta^{2}}}\right) \sqrt{\frac{1+\delta^{2}}{1+\delta^{2} \cos ^{2} \varphi}} \\
& \times\left\{1+\delta^{2} \cos ^{2} \varphi+\frac{\delta^{2}}{2 \alpha} \sin \varphi \cdot F^{\prime}\right\} \cdot F^{\prime}
\end{aligned}
$$

となる.ここに， $\alpha=a / H, \delta=2 \pi a / L, H=h-a$ (平均 水深), $\varphi=2 \pi \xi / L$ (峰側を正とした変曲点からの位相 角) であり，また， $\mathrm{E}(k)$ は第 2 種完全棈円積分

$$
\underline{\underline{E}}(k)=\int_{0}^{\pi / 2} \sqrt{1-k^{2} \sin ^{2} \varphi} \cdot d \varphi
$$

を表わす. 図一11 は, 式 (32) によって求めた正弦波上 の掃流力分布を，種々の波長と波高について，1 周期ず つ示したものである.

ところで, 先に示したように粘着性流路では侵食速度 が掃流力と正の相関をもつから，壁面の凸部における掃 流力が凹部におけるよりも大きければ, 凸部の方が速く 侵食されて凹凸の高さは減少し, 逆に凹部における掃流
力が凸部におけるよりも大きければ，凹部の方が速く侵 食されて凹凸の高さは増加する.そこでそのような凹凸 の盛衰を調べるために, 式 (30) の位相角 $\varphi$ に $\pm \pi / 2$ を代入し，正弦波凹凸の峰と谷における掃流力を求める と,

$$
\tau_{\text {ridge }} / \rho g H I=\{1+(1 / 2) K \alpha(1-\alpha)\}(1-\alpha)
$$

$$
\begin{aligned}
& \tau_{\text {trough }} / \rho g H I \\
& \quad=\left\{\begin{array}{r}
1 /(2 K \alpha) \quad\left[(2 \alpha+1)^{2} \geqq 1+(4 / K)\right. \\
\{1-(1 / 2) K \alpha(1+\alpha)\}(1+\alpha) \\
{\left[(2 \alpha+1)^{2} \leqq 1+(4 / K)\right.}
\end{array} \quad \text { のとき }\right]
\end{aligned}
$$

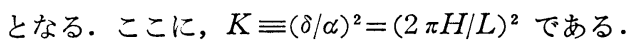

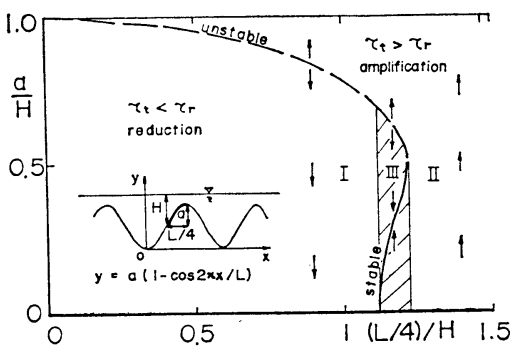

図-12 波高・波長・水深の相対比による 底面凹凸の発達・減衰区分

図一12 は, 式 (33),(34) に基づき, 流路横断面内の 凹凸の増幅と減衰を, 波高 - 波長・水深の相対比によっ て区分したもので，上向きの矢印を付した部分が増幅領 域，下向きの矢印を付した部分が減衰領域，その境界お よび平坦河床が平衡状態となる. 正弦河床波が変形する 場合, その波高が増減するだけで, 変形後も同じ波長を もった正弦波で近似され，しかも平均水深 $H$ が一定に 保たれるものとすれば, 図一12 のある点で表される凹 凸は，侵食時間の経過（平均河床の低下）に伴って，矢 印の方向へ移行することになり，領域Ｉでは減衰を続け てやがて消滅し，領域IIでは発達を続けてやがて水面が 凹凸の峰よりも低くなり，流路が分離する．また領域正 では, 増幅や減衰が生じてもやがてある波高で平衡状態 を保つようになる．図中，太い実線と破線で示した状態 は，いずれも平衡条件（峰と谷の侵食速度が等しいこ と）を満たしているが，前者はそれから少し外れても元
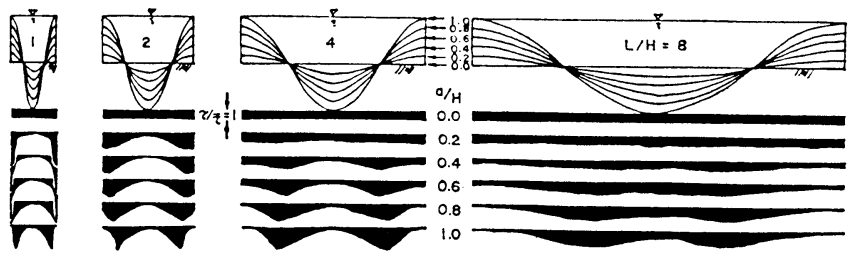

図一11 正弦波状横断面内の掃流力分布（式 (32)）

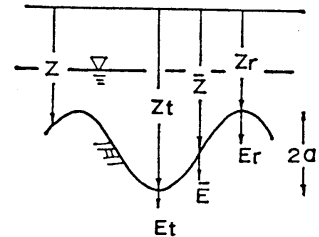

図一13 底面凹凸の各位置における 侵食深ならびに低下速度 
に戻るという意味で安定な平衡状態, 後者は, それから 少しでも外れると別の状態へ移行していくという意味 で, 不安定な平衡状態である.

ところで，図一13 に示すように,ある基準線から凹凸 の峰までの深さを $Z_{r}$, 谷までの深さを $Z_{t}$ とすれば，凹 凸の振幅は,

$$
a=\left(Z_{t}-Z_{r}\right) / 2
$$

であるから，その変化速度は

$$
d a / d t=\left(E_{t}-E_{r}\right) / 2 \fallingdotseq d E / d u_{*} \cdot \Delta u_{*} / 2
$$

となる.ここに, $E_{r}=d Z_{r} / d t, E_{t}=d Z_{t} / d t, \Delta u_{*}=u_{* t}$ - $u_{* r}$ で, $u_{* r}, u_{* t}$ はそれぞれ凹凸の峰と谷における摩 擦速度である. 式 (36) を水深が $H$ の 2 次元流れにお ける侵食速度 $E_{0}$ で基準化し,さらに, 摩擦速度と侵食 速度の関係を,

$$
E \propto u_{*}{ }^{n}
$$

と表示して，その右辺に代入すれば，

$$
(d a / d t) / E_{0} \fallingdotseq(n / 2) \cdot\left(\Delta u_{*} / U_{*}\right)
$$

となる.ここに, $U_{*}(=\sqrt{g H I})$ はそのような 2 次元流 れの摩擦速度である. 特に $n=1$, すなわち,

$$
E / u_{*}=\text { const. }
$$

の場合には, 式 (36), (38) は近似式でなくて, 等式と なる. 前章に示したように, ベントナイト河床で比較的 掃流力の大きい場合には， $n=1$ がほぼ成り立っている.

図一14 は, 式 (38) に式 (33),(34) を代入し, $n=1$ として, 凹凸の振幅の増減速度を求めたもので, 上向き の矢印が増幅, 下向きの矢印が減衰を表わし，いずれも その長さを式 (38) の值に比例させている. また, 増幅 速度の逆数を振幅で積分すれば，振幅の増減に要する時 間 $T$ が求まるが, 積分の始点を振幅が平均水深の $1 / 2$ になる状態に選ぶと, 式 (38) より,

$$
\frac{T}{H / E_{0}}=\frac{E_{0}}{H} \int_{H / 2}^{a} \frac{d t}{d a} d a \fallingdotseq \int_{1 / 2}^{a \mid H} \frac{2 U_{*}}{n \Delta u_{*}} d\left(\frac{a}{H}\right)
$$

となる. 図一14の点線は, $n=1$ でかつ平均水樑 $H$ が

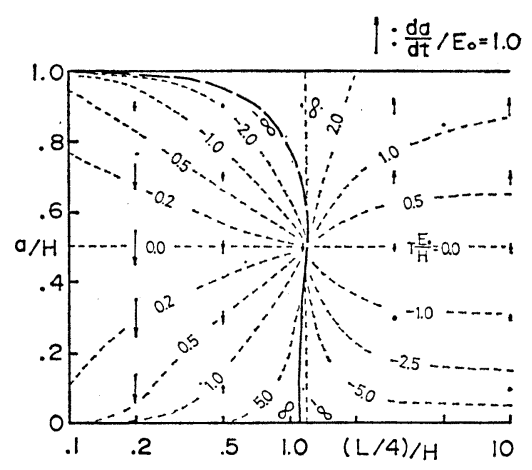

图一14 底面凹凸の增幅減妻速度 (矢印) ならびに基準状態 $(a=0.5)$ から の所要時間 (点線)
時間的に変わらないものとして, 式 (40) の值を求めた ものである.この図からわかるように, 増幅領域と減衰 領域の境界近傍, および波高が小さい領域では, 増幅・減 衰ともその速度が遅く,うね間隔 $(L)$ を一定とすれば, 減衰領域ではその速度 $(|d a / d t|)$ の極大となる波高が存 在するが, 増幅領域では波高が大きくなるほど急速に増 幅する.また，同一波高では一般にうね間隔の狭いもの ほど減衰しやすく, 広いものほど增幅しやすい。

一方, 侵食の進行に伴って, 当然, 平均河床が低下す るが, 正弦波では峰と谷の平均が全体の平均にほかなら ないから，図一13の基準線から平均河床までの梁さを $\bar{z}$ とすれば,

$$
\bar{z}=\left(z_{t}+z_{r}\right) / 2
$$

であり,その低下速度 $\bar{E}$ は，

$$
\left.\bar{E}=d \bar{z} / d t=\left(E_{t}+E_{r}\right) / 2 \fallingdotseq E_{(\bar{u} *)}\right)
$$

となる.ここに， $E_{\left(\bar{u}_{*}\right)}$ は平均摩擦速度 $\bar{u}_{*}\left[=u_{* t}+\right.$ $\left.\left.u_{* r}\right) / 2\right]$ に対する侵食速度である. 式 (42) を $E_{0}$ で基 準化し，さらに式 (37) を用いれば,

$$
\bar{E} / E_{0} \doteqdot\left(\bar{u}_{*} / U_{*}\right)^{n}
$$

となる. また, 振幅が平均水樑 $H$ の半分からある值 $a$ になるまでの, 平均河床の低下量 $Z$ は,

$$
\begin{aligned}
\frac{Z}{H} & =\frac{1}{H} \int_{H / 2}^{a} \frac{d \bar{z}}{d a} d a=\frac{1}{H} \int_{H / 2}^{a} \frac{\bar{E}}{d a / d t} d a \\
& =\int_{1 / 2}^{a / H} \frac{2}{n} \cdot\left(\frac{\bar{u}_{*}}{U_{*}}\right)^{n-1} \frac{\bar{u}_{*}}{\Delta u_{*}} d\left(\frac{a}{H}\right) \cdots \cdots . .
\end{aligned}
$$

となる. 図一15 は, 式 (43), (44) に式 (33), (34)を代 入し, $n=1$ として平均河床の低下速度ならびに低下量 を求めたもので, 矢印が式 (43), 点線が式 (44) の值 を表している.

\section{b）任意形状凹凸の変形}

前項では，無条件に底面凹凸を正弦波で近似したが， その妥当性については検討を要するであ万う.そこで, 本項では前節に述べた一般的な横断面追跡法を用いて， 前項の結果を検討するとともに，種々の擾乱の組み合わ

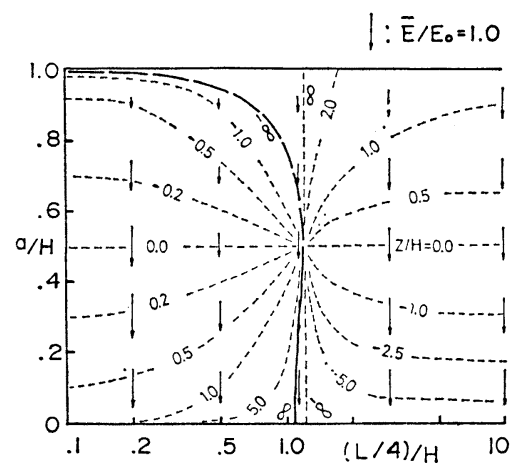




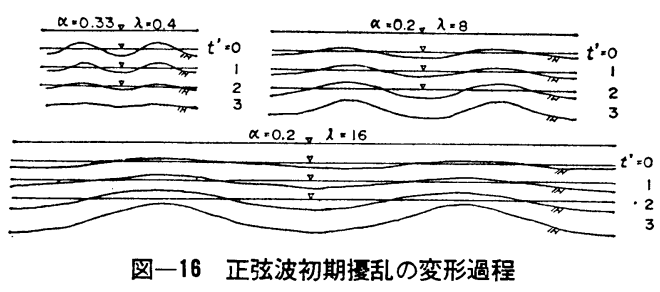

せ効果注いて考察する.

図一16 は,種々の波長の正弦波を初期形状とする擾乱 の変形過程を, 式 (16) の掃流力分布に基づいて追跡し たものである.このように，いずれの波長の場合におい ても, 正弦波の変曲点付近が激しく侵食され, 波形は峰 側のやせたものに変化する. 変形に伴う潤边長の変化は わずかであるから，流量が一定の場合には，式 (28) よ り $f A^{\prime 3}$ の值もさほど変化せず, 横断面形状の変化に伴 う抵抗係数の変化を省略すれば, 断面積一定, すなわち 平均水深一定となる. また, 水位ならびに平均河床の低 下速度も，ほぼ一定である。

一般の波形について, 波長や波高を定義するには, 若 干のあいまいさが伴うが, 図一16 からそれらを読み取 り, その時間的変化を追跡すると, その領域区分や増幅 速度は, 正弦河床波として前節で求めた 図一14 によ。 て,かなり近似できることがわかる．ただし，波長の短 い領域において, 正弦波近似ではきわめて急速に波高が 0 に近づくのに対し, 本項の数值解ではある程度減衰が 進むと, その速度が遅くなり, 損乱は容易に消滅しな い.この場合には, 壁面の法線群が断面内で交錯し, 正 弦波近似はもちろんのこと, 式 (17) も成り立たなくな っている.

次に, 図一17 は2つの異なる波長の正弦波の重社合 わせから成る初期擾乱の変形過程を調べたものである.

挸乱の与え方は,

$$
\eta^{\prime}=\alpha_{1} \cos \left(\pi \xi^{\prime} / \lambda_{1}\right)+\alpha_{2} \cos \left(\pi \xi^{\prime} / \lambda_{2}+\delta\right)
$$

としている. 図からわかるように, 凹凸の変形速度や, 流路の分裂のしかたには, 明らかに 2 成分の干涉効果が 現れるが，(a) の場合には合成波の 2 つのピークがとも に減衰，(b) の場合には片方のピークだけが発達，(c) 以下の場合にはどちらのピークも発達し，いずれの場合 もそれらの成分波が単独に存在する場合の発達・減衰区

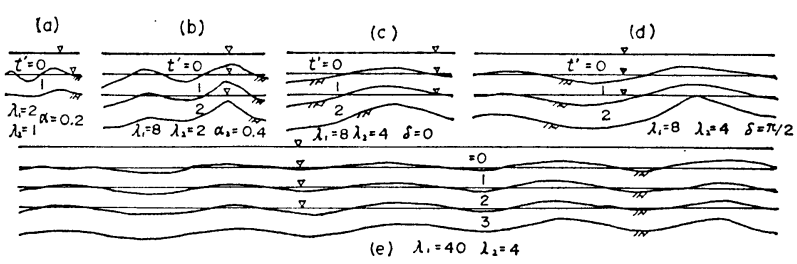

図一17 正弦波鈸乱の重ね合わせ効果
分が保存されてい る.

図一18は,さらに 一般的な場合とし $\tau$, 正弦波に不規則 擾乱を重㸚合わせ て, その変形過程を 追跡したものであ る.これによると比

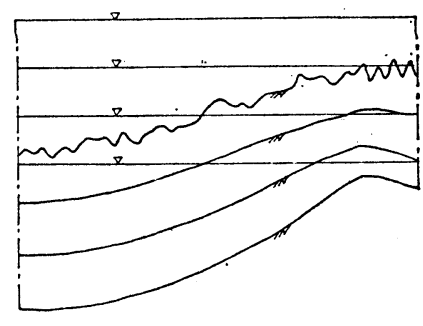

図-18 不規則擭乱の重ね合わ せ効果
較的短波長の擾乱は急速に減衰し, 長波長のものだけが 選択的に発達している.

c）リルの発生

先にも述べたように, 流路の横断方向には種々の規模 の擾乱が混在しており, そのうちのあるものは侵食の進 行に伴って発達し, 流路の分裂が生じるが, これは裸地 斜面におけるリルの発生機構にほかならないものと考え られる.

ところで, 流路幅 $B$ が有限の場合, 横断方向の凹凸 に関与する擾乱は，

$$
L / B<1 / 2
$$

のものである.ここに，Lは擾乱の波長である.したが って, 有限な幅をもつ平坦なシートフロー (sheet flow) から横断方向の凹凸が発達する条件は, 式 (46) を満た す微小挸乱に対する, 底面の安定・不安定問題として解 析できるであろう. 前項の 図一12 からわかるように, 粘着性材料加らる平坦河床は,

$$
(L / 4) / H \leqq \sqrt{2} \pi / 4 \doteqdot 1.1
$$

の正弦微小擾乱に対して, それぞれ安定・中立・不安定 である.また，不安定となる擾乱のうち，発達して流路 の分裂にまで至るのは，

$$
(L / 4) / H>\pi / 4 \sqrt{\sqrt{2}-1} \fallingdotseq 1.2
$$

のものである. したがって, そのような擾乱が存在し て, 流路の分裂が生じるための条件（リルの発生条件） は, 式 (46),(48) より,

$$
B / H>2 \pi \sqrt{\sqrt{2}-1} \fallingdotseq 10
$$

となる.そして，流れが式（49）の条件を満たしている 間は, 式 (46) と（49）を同時に満たす擾乱のうち, 最 も速く水面に達するものによって, 流れが次々に分裂す る.しかし，その分裂のしかたは，初期の波長と波高の 分布状態依存し，与えられた水理条件や土質条 件に対して，必ずしも一意的であるとは限らない。

また，そのような分裂が生じるのにどの程度の 時間がかかるかも,初期状態に依存し，図一14 亿 示したように初期波高が小さければその時間は急 増する。

\section{d) 実験的検証}

そこで, 以上の理論結果を検証し，さらに問題 
表一1 底面凹凸の変形に関する実験（Series A) の概要

\begin{tabular}{|c|c|c|c|c|c|c|c|c|c|c|c|c|c|c|c|}
\hline & & Run 1 & Run 2 & Run 3 & Run 4 & Run 5 & Run 6 & Run 7 & Run 8 & Run 9 & Run 10 & Run 11 & Run 12 & Run 13 & $\overline{\text { Run } 14}$ \\
\hline \multirow{5}{*}{$\begin{array}{l}\text { 実 } \\
\text { 験 } \\
\text { 条 } \\
\text { 件 }\end{array}$} & $Q(l / \mathrm{s})$ & 0.1 & 0.6 & 0.15 & 0.6 & 0.15 & 1.2 & 0.6 & 0.15 & 0.6 & 0.3 & 0.15 & 6.6 & 6.6 & 4.3 \\
\hline & $I$ & $1 / 5$ & $1 / 20$ & $3 / 10$ & $1 / 20$ & $3 / 10$ & $1 / 40$ & $1 / 20$ & $3 / 10$ & $1 / 20$ & $1 / 5$ & $3 / 10$ & $1 / 20$ & $1 / 20$ & $1 / 20$ \\
\hline & $H(\mathrm{~cm})$ & 0.17 & 0.85 & 0.35 & 1.1 & 0.4 & 2.5 & 0.8 & 0.45 & 0.9 & 0.4 & 0.3 & 1.5 & 1.0 & 0.8 \\
\hline & $L(\mathrm{~cm})$ & 7 & \multicolumn{2}{|c|}{0.5} & \multicolumn{2}{|c|}{1} & \multicolumn{3}{|c|}{2} & \multicolumn{3}{|c|}{4} & 100 & \multicolumn{2}{|r|}{4} \\
\hline & $a(\mathrm{~cm})$ & \multicolumn{11}{|c|}{0.25} & \multicolumn{3}{|c|}{0.50} \\
\hline \multirow{2}{*}{ 実 } & $\begin{array}{l}t(\mathrm{~min}) \\
a(\mathrm{~cm})\end{array}$ & $\begin{array}{l}10 \\
0.05\end{array}$ & $\begin{array}{l}5 \\
0.04\end{array}$ & $\begin{array}{l}5 \\
0.04\end{array}$ & $\begin{array}{l}10 \\
0.15\end{array}$ & $\begin{array}{l}5 \\
0.15\end{array}$ & $\begin{array}{l}5 \\
0.25\end{array}$ & $\begin{array}{l}5 \\
0.23\end{array}$ & $\begin{array}{c}5 \\
>H\end{array}$ & $\begin{array}{l}5 \\
0.25\end{array}$ & $\begin{array}{l}5 \\
0.38\end{array}$ & $\begin{array}{c}5 \\
>H\end{array}$ & $\begin{array}{l}16 \\
0.10\end{array}$ & $\begin{array}{l}16 \\
0.60\end{array}$ & $\begin{array}{l}48 \\
0.45\end{array}$ \\
\hline & $\begin{array}{l}t(\mathrm{~min}) \\
a(\mathrm{~cm})\end{array}$ & $\begin{array}{l}20 \\
0.07\end{array}$ & $\begin{array}{l}10 \\
0.04\end{array}$ & $\begin{array}{l}10 \\
0.04\end{array}$ & $\begin{array}{l}20 \\
0.10\end{array}$ & $\begin{array}{l}10 \\
0.07\end{array}$ & $\begin{array}{l}10 \\
0.22\end{array}$ & $\begin{array}{l}10 \\
0.20\end{array}$ & & $\begin{array}{l}10 \\
0.25\end{array}$ & & & $\begin{array}{l}45 \\
0.15\end{array}$ & $\begin{array}{l}45 \\
0.45\end{array}$ & \\
\hline \multirow{2}{*}{$\begin{array}{l}\text { 桔 } \\
\text { 果 }\end{array}$} & $\begin{array}{l}t(\mathrm{~min}) \\
a(\mathrm{~cm})\end{array}$ & & & & $\begin{array}{l}30 \\
0.10\end{array}$ & $\begin{array}{l}15 \\
0.07\end{array}$ & $\begin{array}{l}15 \\
0.18\end{array}$ & $\begin{array}{l}15 \\
0.19\end{array}$ & $\begin{array}{l}15 \\
0.15\end{array}$ & $\begin{array}{l}15 \\
0.25\end{array}$ & & & $\begin{array}{l}75 \\
0.40\end{array}$ & & \\
\hline & $\begin{array}{c}t(\min ) \\
B / h\end{array}$ & & & & & & & & $\begin{array}{l}5 \\
2.82\end{array}$ & & $\begin{array}{l}15 \\
3.73\end{array}$ & $\begin{array}{l}15 \\
3.37\end{array}$ & & & $\begin{array}{l}48 \\
3.41\end{array}$ \\
\hline
\end{tabular}

水路幅 : Run 1 11 7cm, Run 12 14 $100 \mathrm{~cm} \quad B / h$ : 分離した流路の水面幅最大水深比

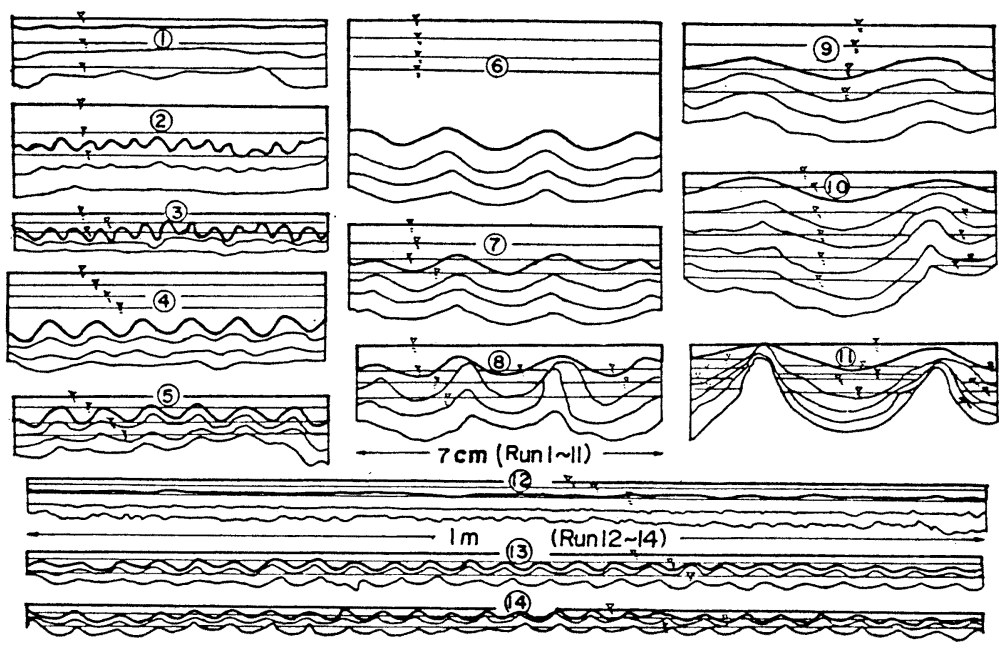

図一19 実験（Series A) における流路横断面形状 (水平線 : 水面, 曲線 : 流路床, 太線 : 初期状態)
れらの特徴は, 先に 図一11に 示した掃流力分布から十分に説 明できるものである.

図一20 は, Series A の実験 結果を 図一14 の平面上で追跡 したもので, 先の理論によって その変形過程をある程度定量的 に模擬できることがわかる.た だし，図中の数字は，通水時間 を平均水深と平均河床低下速度 の比で割った值である.この中 で Run 8 の動きは複雑で, 通 水初期に増幅が生じていったん 流路が分裂したのち, 再び合体 して減衰に移行している.これ は, 初期状態においては峰部よ りも谷部の侵食が速いために,
点を検討するために，水路実験を行った (Series A). 使用材料は前章に述べた実験と同じく，砂とベントナイ 卜と水を重量比 $9: 1: 3$ 亿練り混ぜたもので, 表一1 お よび 図一19に，その実験条件ならびに結果を示してい る.

まずその概要を定性的に述べると，次のようである． すなわち, Run 2 5 のようにうね間隔の狭い凹凸を与 えると，その凹部に比べて凸部の方がきわめて速く侵食 されて波高は急速に減衰するが，Run 11の上うにうね 間隔が広く，かつ水深と波高が同程度の場合には，凸部 に比べて凹部の侵食が速く，波高は増大してやがて流路 が分裂している．また，Run 6 9 のようにその中間的 なうね間隔のものは, 通水開始後まもなく凹凹の変曲点 付近が侵食されて, やや峰のとがった形に変化するが, その後はほぼ一定の形状を保ったまま低下している。 こ
峰部の低下よりも速く水位が低下して峰部が水面上に露 出したが，分離した個々の流路はその水理量に対応する 平衡形状よりも深くて狭いために, 拡幅が生じてオーバ

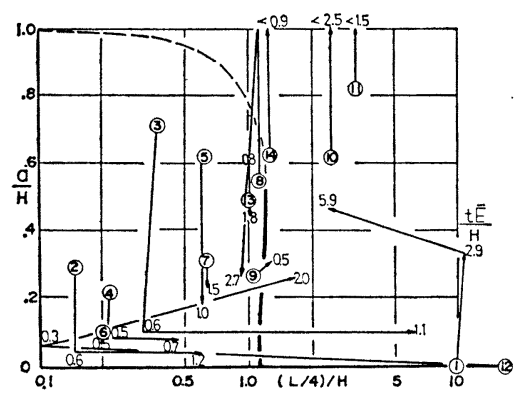

図一20 波長・波高・水深の相対比を表わす 平面上における実験結 果 (Series A) の追跡 
一ハングした部分を崩落させ, その結果流路が合体する と, Run $2 \sim 5$ や 13 と同様に峰部の 掃流力ぶ谷部の掃 流力を上回るようになったものと考えられる. これに対 して Run 11 や 14 の一部においては, 通水初期に凹凸 が発達していったん流路が分裂すると, その後は分離し た流路がそれぞれほぼ一定の形状を保ったまま低下して いる.これは分裂した時点においてそれぞれの流路が平 衡形状よりも扁平で, 中央部が早く侵食され, 流路幅を 減少させながら平衡断面を形成したためと考えられる. この場合にはいったん分離した流路が再び合体すること があるとすれば，拡幅によるものではなくて蛇行による ものであろう. Run 10 は Run 8 と Run 11, 14 の中 間的なものである.

また，この図において Run 9 のように, 時間の経過 とともに横座標 $((L / 4) / H)$ がわずかに移動しているも のがあるのは, 波長 $(L)$ の変化ではなくて侵食の進行 に伴う水深 $(H)$ の変化, 寸なわち抵抗の変化によるも のである. 一方, Run 2, 3, 4 および 12 の後半のよう に, 横座標が右方へ大きく移動しているものは, 種々の 擾乱の中から，波長の大きなものが選択的に残った結果 であり，Run 1 および 12 の前半のように左方へ大きく 移動しているものは, 平坦な初期河床（水路幅を波長と する, 波高 0 の擾乱とみなした）上に，水路幅よりも小 さな波長をもつ新たな凹凸が発生した結果である。この ように, 実際の侵食現象には種々の波長の擾乱が混在し ており, 卓越波長が時間的に変化することもある.

この実験では, 式 (49) のような, 平坦河床からリル が発達して流れを分離させる条件は確認できなかった が, 先にも示したように波高の小さな擾乱は発達領域に おいてもその発達速度がきわめて遅く, それを確認する にはかなり長時間にわたる実験が必要であろう.しかし その場合, 平均河床の 低下量がきわめて大きくなるか ら, 実験装置の規模の制約があって, その確認は困難で ある.もっともここには載せなかったが, 流量を少なく して水深を極端に小さくすれば，平坦河床からでも容易 に凹凸が生長して 流路が分離する. しかしその場合に は, シートフローのもつ土砂輸送能力が小さいために, 侵食と同時に局所的な堆積現象が随所に生じ, 流下方向 に流況が変化して，等流状態が維持されない ${ }^{10)}$.

\section{（4）平衡横断面の形成過程}

\section{a）侵食に伴う横断面の変形}

前節では，横断方向の底面凹凸の変形を論じたが，一 般には側岸を含めた横断面全体としての形状も，侵食の 進行に伴って変化する. その際, ある程度変形が進めば もはやそれ以上変形することなく, 同じ形状を保ったま ま低下が進むような状態, すなわちある種の平衡状態の
存在することが実験 的にも見い出され た.

ここで, 任意の初 期形状をもつ横断面 が，必ず平衡横断面 を形成するか否か， もしも形成するなら ばそれはどのような ものであるか, また それが初期形状に依 存するかどうかとい うことは,きわめて 興味深い問 題であ る.図一21 はその手

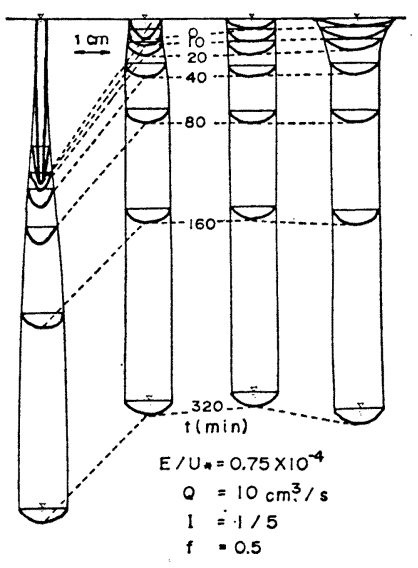

図-21 横断面変形過程の数值 シミュレーション がかりとして，種々の放物線を初期形状とする横断面の 変形過程を数值差分法によって追跡したものである.た だし, 侵食速度と摩擦速度の比や抵抗係数 $f$ などは, あとに述べる実験と対比するため, 図中に示した数值を 用いている.このように初期断面を狭くて深いものにす れば, 拡幅が生じて水深が減少し, 逆に初期断面を広く て浅いものにすれば, 深掘れが生じて流路幅が減少し, 変形速度は異なるが，いずれもほぼ同じ平衡断面に漸近 する.しかしながら、ここに見られる平衡断面の一意性 は，滑らかな放物線で表わされた初期断面に対して得ら れたものであり，前節で述べた発達領域に属する波状の 初期断面に対しては,流れがいくつかに分裂したのち,そ のそれぞれが平衡断面を形成していくものと思われる. その分裂のしかたは, 初期断面における凹凸の波長や波 高の分布ならびにその位相の組み合わせによって異なる であろう。

実際の斜面における地表面の凹凸状況は, 雨水流の水 深程度のスケールから見ればのり面の施工直後といえど もかなり不規則であり,まして崩壊地においてはその程 度がはなはだしい。 また斜面の初期形状だけでなく, 侵 食機構そのものにもここに述べたような決定論的な現象 のほかに, 種々の不規則な現象が介在している. したが って, そのような斜面上の流路の形成過程を一般的に扱 うには, 決定論的な手法だけでなく確率・統計的な手法 も導入せざるを得ないであろう.

b) 平衡横断面形状

前項において, 流路には平衡横断面の存在することが わかったが，このように流路がその横断形状を変えずに 鉛直に低下寸る条件は, 壁面に沿って,

$$
\partial z / \partial t=E / \cos \theta=\text { const. }
$$

が成り立つことである. そこで掃流力と侵食速度の関係 を式 (37) で表わし，座標原点を最媣点に選んで掃流力 


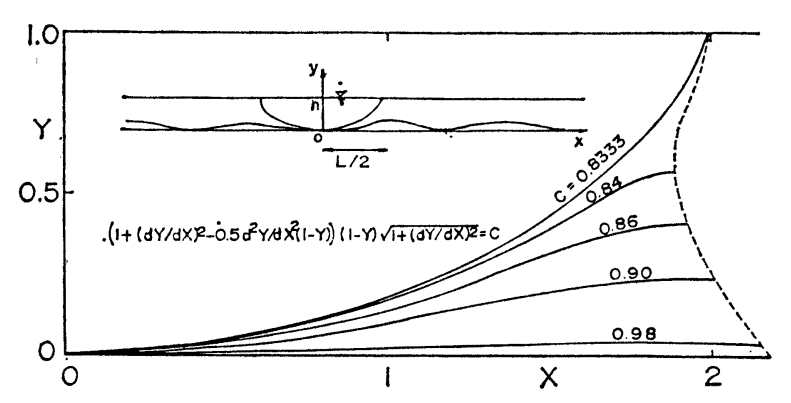

図-22 平衡横断面形状の理論解

を式 (17) で求めれば式 (50) は,

$$
\begin{aligned}
C= & \left\{1+\left(\frac{d Y}{d X}\right)^{2}-\frac{1}{2} \frac{d^{2} Y}{d X^{2}} \cdot F\right\} \\
& \cdot F \cdot\left\{1+\left(\frac{d Y}{d X}\right)^{2}\right\}^{1 / n-1 / 2} \\
F= & \min \left[1-Y, X \frac{d X}{d Y}\right]
\end{aligned}
$$

となる.ここに, $X=x / h, Y=y / h, h$ は最大水深, $C$ は 最深部の掃流力と $\rho g h I$ との比である.

図一22 は,境界条件を $X=0$ において $Y=0, d Y / d X$ $=0$ とおき, $n=1$ として式 (51) を積分したもので $C$ $<0.8333$ の場合には解曲線が水中で直立してその法線 群が交錯し, 本モデルに適合する解が得られないが, $C$ $>0.8333$ の場合には $X \fallingdotseq 2$ で河床高の極大が現われて， らね間隔・最大水深比が約 4 の横断方向の波状河床とな る.ただしその場合には水際が現われず, 流路幅が無限 となるので, 現実の有限の流路に対する解とはなり得な い. そして特に $C \fallingdotseq 0.8333$ の場合にのみ, その峰が水 面と一致し, 水面幅・最大水深比が約 4 の閉じた平衡断 面となる.
このように, 本モデルで求まる平衡断面は流量や 勾配によらず相似であるが，これは掃流力と侵食速 度の関係を式 (39) のようにおいたためであり, 前 章に述べた限界掃流力や式 (37) における指数 $n$ の 変化を考慮すれば断面形状も変わってこよう. しか し, 従来の平衡断面理論 ${ }^{15}$ に見られるような, 流路 の中央における平坦部の幅の任意性は除去されてい る.これは, 本理論では, 掃流力の算定に壁面の曲 率が導入されていることに基づいている.

表一2 および 図一23 は, 粘着性流路における平 衡横断面の形成過程について行った水路実験の実験 条件ならびに結果である (Series B). 使用材料は, Run 1 9 が先の実験 (Series A) と同じく,砂・ベントナイ 卜混合物, Run 10 は京都市西部の 洛西ニュータウンで 採取した，竹林跡の土砂である. 初期断面はいずれも幅 約 $1 \mathrm{~cm}$ の長方形としたが，通水開始後まもなく放物線 形に変化する. その後, 低下に伴って縦断面形状は階段 状となり, 流路位置演横へもかなり振れるが, 流水断面 はそれらの変動に対して比較的すみやかに調節されて，

Run 1 と Run 5 を除けば時間的にさほど変化していな い(Run 1, 5 は，いったん分離した流路が，測定位置よ りも上流で蛇行のために合流し, 一方が涸渇して他方の 流量を増加させたものである).

流量や勾配を変えれば, 断面の大きさはもちろんそれ に依存して変化するが，その形状には系統的な差異が見 い出し難く, 水面幅・最大水深比が約 3 4 の範囲に分 布している.これは理論によって得られた值, 寸なおち $B / h \fallingdotseq 4$ にかなり近い. 実験において水面よりも上部の 溝幅が水面幅に比べて広いのは, 流れの横変動や側壁の 崩落によるものと思われる.

また，前節に示した先の実験 (Series A) の Run 6〜9 におい て，通水初期の変形後に見られる ほぼ一定の形状を本節で理論的に 得られた波状の平衡断面と比較す ると, 実験で得られるものには， 波長・最大水深比が理諭值 (約 4) に比べてはるかに小さいもの が含まれており，峰部もかなりと がっている.これらが実際に平衡 形状であるのか，それとも単に変 形速度が遅いだけでもっと別の平 衡形状へと移行していく過渡的な 段階にあるのかは判定し難いが， いずれにしても掃流力を式 (17) で算定する限り，そのような峰部 のとがりを説明することはでき 
ず，さらにらせん流などの 2 次流の効果 ${ }^{16), 17)}$ を考慮す る必要があろう。

さて，断面形状がわかれば，抵抗係数を与えることに よって, 流量や勾配と水深（あるいは流路幅）の関倸が 導かれるが, 斜面侵食流路の抵抗には断面形の効果を無 視できない上に, 蛇行や階段状の縦断形 ${ }^{18)}$ の影響など未 知の要素が多く, それを明らかにしていくことは今後に 残された課題である.なお, 粘着性材料上の流路形成過 程と形態的に類似した現象が, 融水による雪水の侵食過 程 ${ }^{19)}$ にも見られることは興味深い.

\section{4. 結論}

以上, 従来研究の立ち遅れている, 粘着性流路床の土 砂水理学を進展させるための基礎として, 粘土分を含有 する砂れき床の侵食ならびに流砂機構に基づいて, 平坦 な流路床にリルが形成されていく過程，ならびに形成さ れた流路の横断面が平衡形状に移行していく過程を理論 的に考察し，実験によってその適用性を検討した．得ら れた結果を要約すると次のようである.

（1）粘土の侵食速度は水流の条件だけでなく，その 鉱物組成や存在状態によって異なるが，一般に掃流力と 正の相関をもつものと考えられる.特にベントナイトの 場合には, 含水比を一定とすれば, 大きな掃流力の範囲 で侵食速度が摩擦速度に比例し, その倸数は $10^{-5}$ のオ ーダーをもつことが実験的に得られた。

（2）粘土分を含有する砂れき床の受食性は, 従来, その材料に固有のものとして取り扱われてきたが, 本研 究では個々の砂れきの侵食の過程を周囲の粘土がはく離 して砂れきが移動しやすい状態になる過程と，そのよう な状態になったのち実際に砂れきが移動するまでの過程 とに分けることによって, 粘土の侵食速度と砂れき床の 平衡流砂量から混合物の侵食速度を求めるモデルを考案 し，式中の係数を実験によって定めることができた.

（3）流砂量が流水のもつ土砂輸送能力に満たなけれ ば, 侵食が進行するがその速度は流砂量そのものにはあ まり影響されずに，掃流力と河床材料によって決まり， 掃流力が一定の場合には平衡流砂量に達するまで河床は ほほ平行に低下し, 流砂量は距離に比例して増加するこ とが確かめられた.

（4）等流における流路横断面内の掃流力分布は, 等 流速線にたてた直截線にはさまれる部分の面積をその潤 辺長で微分することによって得られるが, 等流速線を壁 面からの等距離線で近似することによってその直截線を 壁面にたてた法線で表わすことを提案し, 任意断面の掃 流力分布を求める式を導いた. この式には壁面の曲率が 合まれており，上に凸の部分では掃流力が集中し凹の部
分では分散することが定量的に表されている.

（5）上の掃流力分布と侵食特性を用いることによ。 て, 任意の横断面の変形過程を追跡するモデルが組み立 てられ, 粘着性流路床における極端に波長の短い凹凸は 侵食の進行に伴って平滑化され, 水深 $(H)$ に比べて波 長 $(L)$ の大きな凹凸 $(L / H \geq 5)$ は発達して流れを分裂 させるようになることが導かれた.

種々の波長の挸乱が組み合わさっている場合には，そ れらの干涉効果が現われて, 変形速度や分裂のしかたは 成分波の組み合わさり方によって異なるが，それらの発 達・減衰区分は, それぞれの成分波が単独に存在する場 合のものが保たれる．したがって，幅の広い流れは，何 らかの原因によって生じる発達領域の擾乱によって, あ る平衡条件を満たすまで次々に分離する.

（6）上記のモデルを放物線で近似されるような横断 面に適用することによって, 初期形状が広くて浅い断面 は底面の一部に深掘れを生じて流路幅が減少し, 初期形 状が狭くて深い断面は拡幅を生じて水深が減少し，いず れもほぼ同一の平衡断面に漸近していく過程を追跡し た. 壁面の後退速度が摩擦速度に比例する場合には, こ の平衡断面は流量や勾配によらず相似で水面幅・最大水 深比が約 4 となる.

（7）流路の横断形状特性がわかれば, 水流の抵抗則 を与えることによって, 流量や勾配と断面の大きさの関 係が得られるが, 抵抗則は流路の縦・横断ならびに平面 形状と密接に関連しており，一般的な把握が困難であ る.また，本研究では流れを等流として 2 次流の影響を 省略したが，実際の流れは複雑で場所によって状態が異 なるから，掃流力分布の算定法もさらに改良する必要が ある.

（8）本研究ではおもに決定論的な観点から流路横断 面の形成過程を論じたが, 水文条件・地形条件・土質条 件, さらには水理学的な流れの機構の中にも不規則性の 存在は避け難く, 実際問題への適用にあたっては, 確 率・統計的な手法を組み合わせていく必要があろう.

\section{参考文 献}

1) Task Committee on Erosion of Cohesive Materials : Erosion of cohesive sediments, Proc. of ASCE, Vol. 94, No. HY 4, 1968.

2）田中 茂: 急斜面土壤浸蝕の機構に就て, 土木学会誌, 第 33 巻, 4 号, 1948.

3) Dunn, Irving, S. : Tractive resistance of cohesive channels, Proc. of ASCE, Vol. 85, No. SM 3, 1959.

4) Smerdon, E.T. and Beasley, R.P. : Tractive force theory applied to stability of open channels in cohesive soils, Research Bulletin No. 715, Agricultural Experiment Station, Univ. of Missouri, Columbia, Mo., 1959.

5) Partheniades, E. : Erosion and Deposition of Cohesive Materials, River Mechanics, Vol. II, ed. by H.W. Shen, 1971. 
6）芦田和男・田中健二 : 粘土分を含有する 砂れき床の侵食 之流砂機構に関する研究, 京都大学防災研究所年報, 第 17 号 B, 1974.

7）矢野勝正・土屋義人・道上正規 : 砂れきの 流送機構の 確 率過程としての特性について, 京都大学防災研究所年報, 第 11 号 B， 1968.

8）岩垣雄一・土屋義人：雨水流による土砂の剥離と輸送に ついて, 土木学会論文集, 第 51 号, 1957.

9) Agricultural Research Service, USDA : A universal equation for predicting rainfall-erosion losses, ARS 22-66, 1961.

10）芦田和男・田中健二：裸地斜面における 流路の形成過程 に関する研究 (1) 一一流路網の確率的シミュレーション を中心として—, 京都大学防災研究所年報, 第 18 号 B, 1975.

11）芦田和男・奥村武信・田中健二 : 斜面侵食に関する実験 的研究, 京都大学防災研究所年報, 第 16 号 $\mathrm{B}, 1973$.

12）芦田和男 - 澤井健二 : 粘着性河床における 流路横断面形 状, 第 20 回水理講演会論文集, 1976 .
13) Graf, W.H. : Hydraulics of Sediment Transport, McGraw Hill, p. 112, 1971.

14）芦田和男・澤井健二 : 粘着性流路床における 横断方向凹 凸の発達過程 : 第 21 回水理講演会論文集, 1977.

15) Lane, E.W. : Progress report on studies on the design of stable channels of the Bureau of Reclamation, Proc. ASCE, Vol. 79, 1953.

16）木下良作：航空写真による 洪水流の流況測定, 水工学 リーズ 68-12, 土木学会水理委員会, 1968.

17) Allen, J.R.L. : Transverse erosional marks of mud and rock: Their physical basis and geological significance, Sediment Geol., 5, p. 320, 1971.

18）芦田和男・澤井健二・藤田 学: 宅造地法面における侵食 流路形態, 土木学会関西支部年次学術講演 会 概 要 集, 1976.

19) Parker, G. : Meandering of superglacial melt streams, Water Resources Research, Vol. 11, No. 4, 1975 .

(1977.1.17 · 受付) 